\title{
The High Levels of Excess Reserves 2008-2012: An Investigation into the Determinants of the U.S. Banks' Liquidity Hoarding during the Global Financial Crisis
}

\author{
Mary Mattingly ${ }^{1, *}$, Ahmed S. Abou-Zaid ${ }^{1,2}$ \\ ${ }^{1}$ Department of Economics, Eastern Illinois University, USA \\ ${ }^{2}$ Suez University, Egypt
}

Copyright $@ 2015$ Horizon Research Publishing All rights reserved.

\begin{abstract}
Excess reserves, the indication of a bank's opportunity to invest, have historically been quite predictable and low for many years. From early sixties to August of 2008, the percentage of excess reserves in relation to required reserves has been between $1 \%$ to $9 \%$. In September 2008, shortly prior to the tipping point of the 2008 financial crisis, the level of excess reserves began to rise dramatically and has stayed quite high even four years later. The watershed moment of Lehman Brothers and AIG failing precipitated a banking panic that involved drastic policy changes by the Fed and financial firms scrambling to find liquidity in anticipation of a credit crunch and drawdowns of credit lines. In less than six months, excess reserves ballooned to over $\$ 900$ billion, which accounts to $2,063 \%$ of required reserves. Surprisingly, the large amount of excess reserves did not return to the previous levels. Instead, it has increased even more to nearly $\$ 2$ trillion. This paper thus investigates the determinants for banks to hoard liquidity. The data reveals that high losses in loans and investments have caused banks to prognosticate higher levels of precautionary reserves. Furthermore, the very low federal funds rate and high unemployment rate have given banks limited opportunities to use the reserves in other alternative investment vehicles. Finally, the Federal Reserve's decision to pay interest on excess reserves provided incentives for banks and made holding reserves above the required amount no longer a cost for the bank.
\end{abstract}

Keywords Excess Reserves, Federal Reserve Policy, Federal Fund Rate, Financial Crisis, Great Recession, Liquidity Hoarding

\section{Introduction}

Banks financing and intermediation have always been a critical part of any economy and a major contributor to the country's economic growth. That is, if the banking system malfunctions, this can have drastic consequences on the health and the performance of the economy. Consequently, bank's investment, notably through advancing loans, is crucial for the economy. An indication of a bank's opportunity to invest is its level of excess reserves and how they decide to use these reserves. Excess reserves have historically been quite predictable and low for many decades because it was costly for the banks to hold on to them and not to earn profit on the funds. However, the large amount of defaults on banks' loans since 2007 has increased the level of risk associated with any loan, which resulted, among other factors, in liquidity hoarding. Note that the liquidity hoarding phenomenon is not new. In the aftermath of Great Depression, and particularly during the late 1930s, US commercial banks accumulated substantial amounts of voluntary excess reserves. Ramos [20] explains this phenomenon by pointing out that during and immediately after any severe liquidity crisis, banks hoard excess cash to self-insure against further drains of cash and to send markets a strong message that their solvency is not at risk and that bank runs are not justifiable. From 1959 to August of 2008, the percentage of excess reserves in relation to required reserves had been around one to nine percent, except for the month of September 2001, when the U.S. experienced terrorist attacks and banks reacted by holding higher levels of excess reserves. The level rose to a high of $50 \%$ of required reserves, but the ratio returned to normal levels in the following month (Federal Reserve Economic Data, FRED). However, in September 2008 the level of excess reserves began to rise dramatically and has stayed quite high even four years later. The highest it reached was 2,063\% of required reserves and currently it accounts for almost $1,322 \%$ (FRED). The current banks behavior clearly resembles their behavior during crisis of the 1930s. The main objective of this paper is to evaluate the incentives that lead to the increase of excess reserves and investigate why banks are continuing to hoard this high level of liquidity. The remainder of this paper is designed as section 2 describes 
literature review and theoretical underpinnings; section 3 presents hypothesis and model; section 4 demonstrates results and discussion; section 5 shows robustness checking and the final section presents conclusion and future research.

\section{Literature Review and Theoretical Underpinnings}

Several theoretical papers have focused on examining the motivation for banks to hoard liquid assets. Several banks may decide to hoard liquidity for precautionary reasons if they believe that will be unable to obtain interbank loans when they are affected by temporary liquidity shortages (Allen and Gale, [3]). Gale and Yorulmazer [10], and Diamond and Rajan [7] argue that precautionary liquidity hoarding occurs as banks' response to the fear of forced asset liquidation. That is, banks hoard liquidity in anticipation of high expected return from holding cash. In the model of Gale and Yorulmazer [10], banks hoard liquidity to protect themselves against future liquidity shocks (precautionary motive) or to take advantage of potential sales (strategic motive). Recent empirical evidence on liquidity hoarding in both U.S. and Europe is provided by Acharya and Merrouche [1], Heider, Hoerova, and Holthausen [13], Haan and Van den End [12], and Ennis and Wolman [9]. Acharya and Merrouche [1], using data for large settlement banks in the UK, show that banks significantly increased their liquidity buffers after August 2007. This increase in liquid assets occurred when the interbank markets started to dry up and bank borrowing costs increased. Heider, Hoerova and Holthausen [13] also provide evidence of liquidity hoarding in the euro interbank market. Unlike the very small spreads and infinitesimal amounts of excess reserves in normal times, they show that the unsecured euro interbank market exhibited significantly higher spreads leading to a dramatic increase in banks' excess reserves. Haan and Van Den End [12], using a panel vector auto-regression (P-VAR), find that in response to funding liquidity shocks, Dutch banks reduce wholesale lending, hoard liquidity in the form of liquid bonds and central bank reserves, and conduct fire sales of equity securities. Finally, Ennis and Wolman [9], using data on US commercial banks, find that banks holding large excess reserves at the Federal Reserve since the fall of 2008 also increased their holdings of other liquid assets such as short-term securities. Their findings furthermore indicate that banks holding high levels of liquidity have enough capital to expand their lending without facing binding capital requirements.

In the U.S., the level of excess reserves in the banking system can be manipulated by the Federal Reserve Bank. Akhtar [2] argues "the basic link between monetary policy and the economy is through the market for bank reserves". The Federal Open Market Committee (FOMC) uses open market operations to raise or lower the federal funds rate. They cannot directly change the federal funds rate, but must do so by changing the "supply of or demand for reserves" and that change helps the committee achieve their targeted rate. The Committee's goal is to use the level of reserves and the federal funds rate to hopefully create "stable prices, full employment and, more generally, a stable financial environment for the economy".

What caused this increase in excess reserves? Are banks holding on to more consumer deposits or borrowing reserves from the Federal Reserve? By looking at Figure 1, we see that nearly all of the increase in excess reserves is from borrowed reserves. In fact, $99.98 \%$ of the total reserves are borrowed, leaving only . $02 \%$ of excess reserves coming from customer deposits.

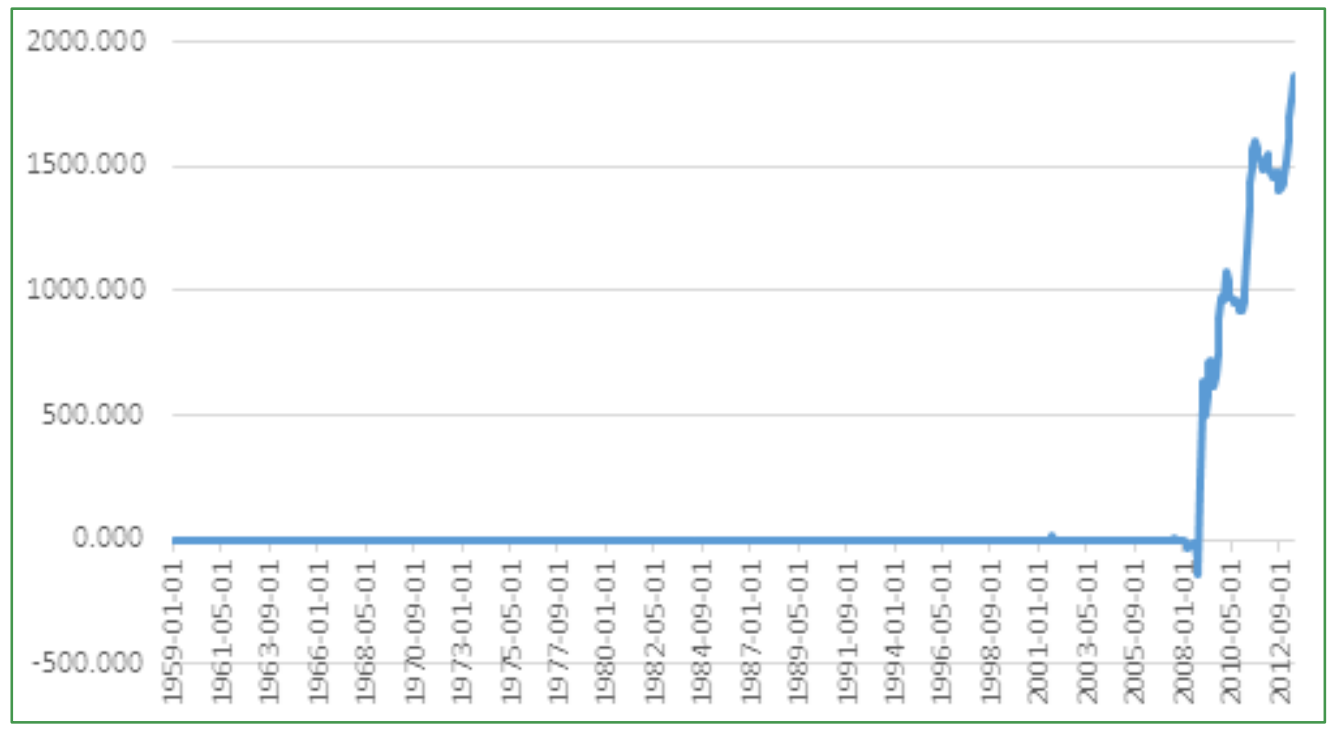

Figure 1. Borrowed Reserves of Depository Institutions 
But why did the Federal Reserve feel the need to take such dramatic action and give banks such high amounts of reserves? We must look at the Fall of 2007 to understand the circumstances that brought us here today. In August of 2007, banks began to experience a "bank run," but not a traditional run where customers run to a bank to withdrawal their cash, "this run was invisible to almost everyone because it was a run by banks and firms on other banks" (Gorton, [11]). As mentioned before, the federal funds market keeps money flowing to where it is needed because the banks know each other and know their condition, but in 2007 that system fell apart. As Lanchester [16] states, "if the global economic crisis can be reduced to one single phenomenon, it is this: the fact that nobody knows which banks are solvent". In fact, the Chairman of the Federal Reserve, Ben Bernanke [4] explained to the committee on Financial Services that at the time, if banks even asked for funds from another bank, they were "perceived as weak" and banks became reluctant to trade with each other. The answer to this problem was for the Federal Reserve to step in and support the banking system and to provide liquidity to keep credit flowing. These first loans to banks were "sterilized via open market sales of securities," so the Fed's balance sheet increased, but reserves stayed the same (Ennis and Wolman [9]). These purchases drove the federal funds rate down to almost zero, which is the lower bound for the rate (Bernanke, [4]). To increase the Federal Reserve's monetary policy tools, the Central Bank also began paying interest on excess reserves at a rate of .25\% in October of 2008 (Bernanke [4]). Once this program began, the Federal Reserve stopped sterilizing the purchases and the level of excess reserves began to quickly increase (Ennis and Wolman [9]). In addition, in September of 2008 many large banks began to default and the US stock market started to plunge. Before the 2007/2008 crisis, banks had made very risky mortgage loans and were combining and selling those loans using complicated financial vehicles and swaps (Lanchester, [16]). The Federal Reserve intervened with purchases of bank held mortgage-backed securities in exchange for ready access liquidity hoping to keep the entire banking system from collapsing. As Figure 2 shows, the amount of mortgage-backed securities held by the Federal Reserve went from zero to a high of almost $\$ 1.2$ trillion dollars. As the report prepared by the Federal Open Market Committee (2012) explains these actions were used to "support conditions in the mortgage markets".

These programs kept the banking system from complete catastrophe, and kept credit and liquidity available to consumers. As Bernanke [4] said during his testimony, these steps "proved effective for injecting liquidity into the financial system". But what have the banks done with these huge liquidity injections? It has been over five years since the beginning of the banking panic in 2007 and banks are still holding on to nearly the same levels of reserves as when the U.S. was deep in the economic recession. Why are banks so reluctant to lend and are continuing to hoard the money received from the Federal Reserve Bank?

Edlin and Jaffee [8] suggest that banks' level of capitalization may be too low after the risky loans they made in the middle 2000s and they are now working on increasing their capital ratios. Lanchester [16] also mentions this problem in his book. He says that banks are given "two totally incompatible goals," because they need to "rebuild their balance sheets and recapitalize themselves so they're no longer at risk of going broke" but they also need to continue to extend loans to stimulate the economy. In addition to undercapitalization, many banks are worried about past risky loans and investments and are afraid of greater losses in the future than they anticipated.

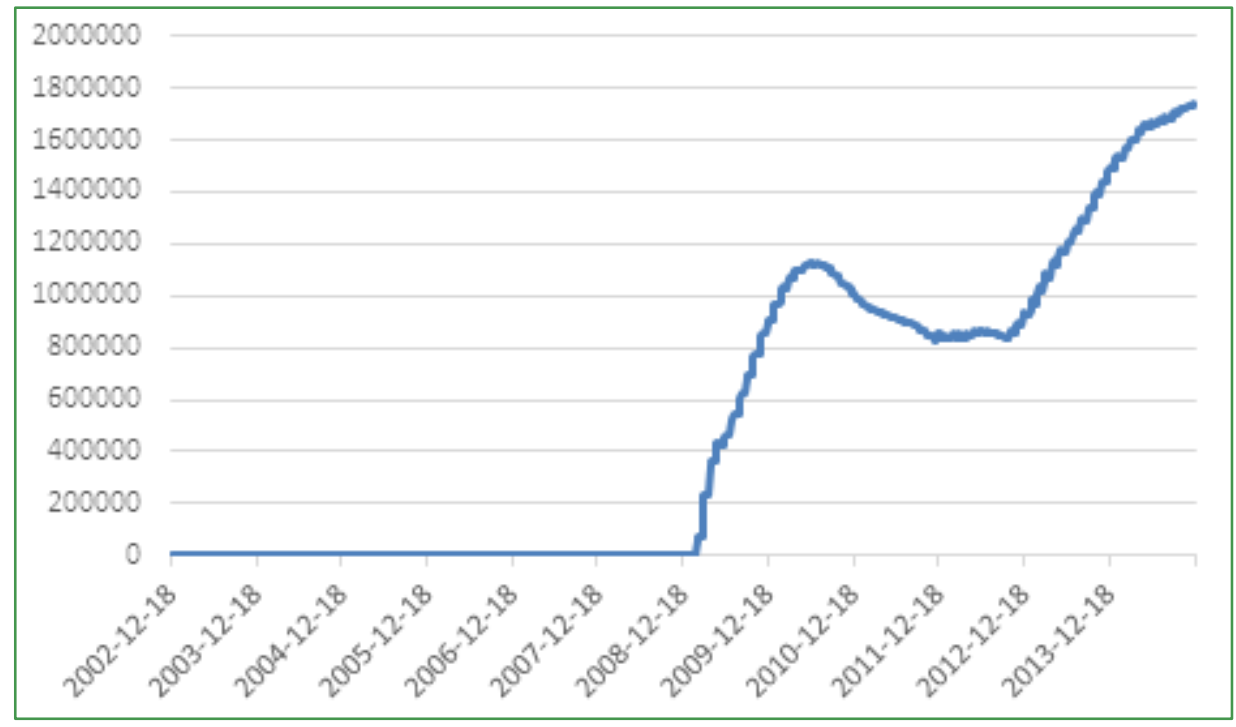

Figure 2. Mortgage-Backed securities held by the Federal Reserve (2003-2013) 


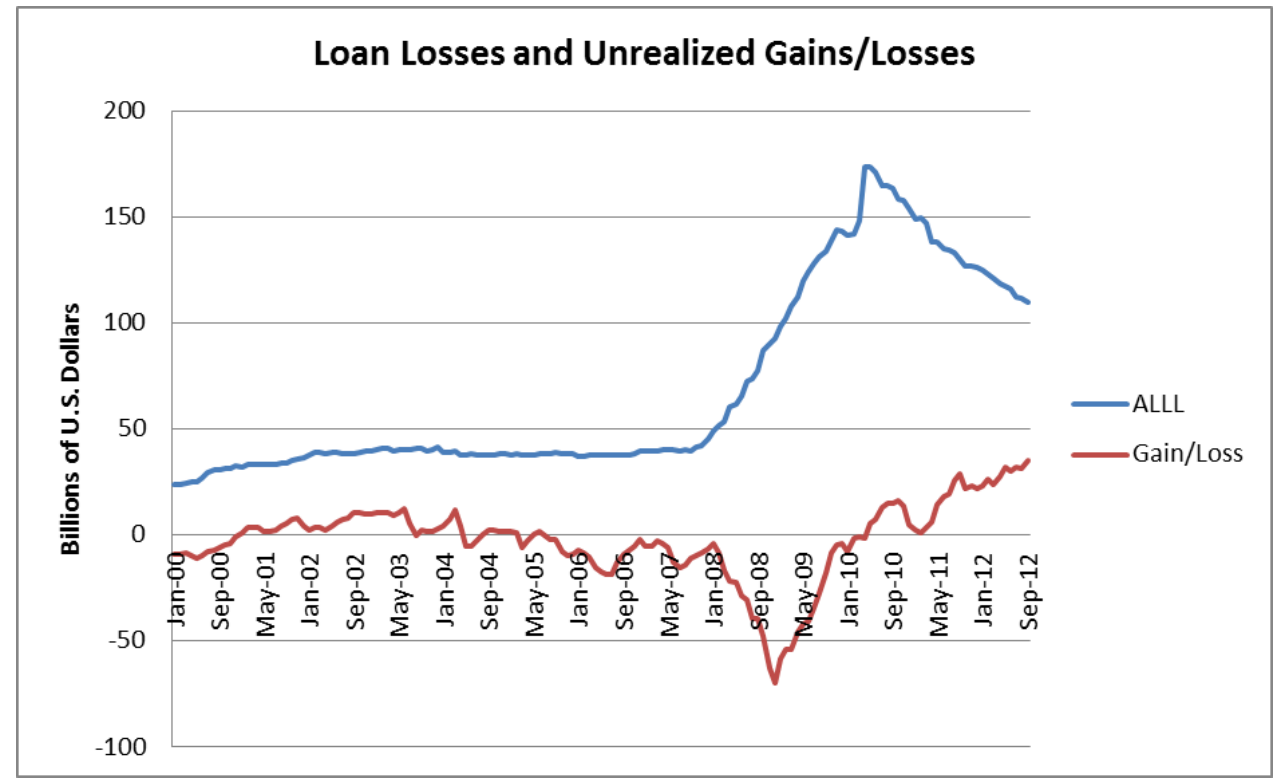

Figure 3. Loan Losses and Unrealized Gains/Losses (2000-2012)

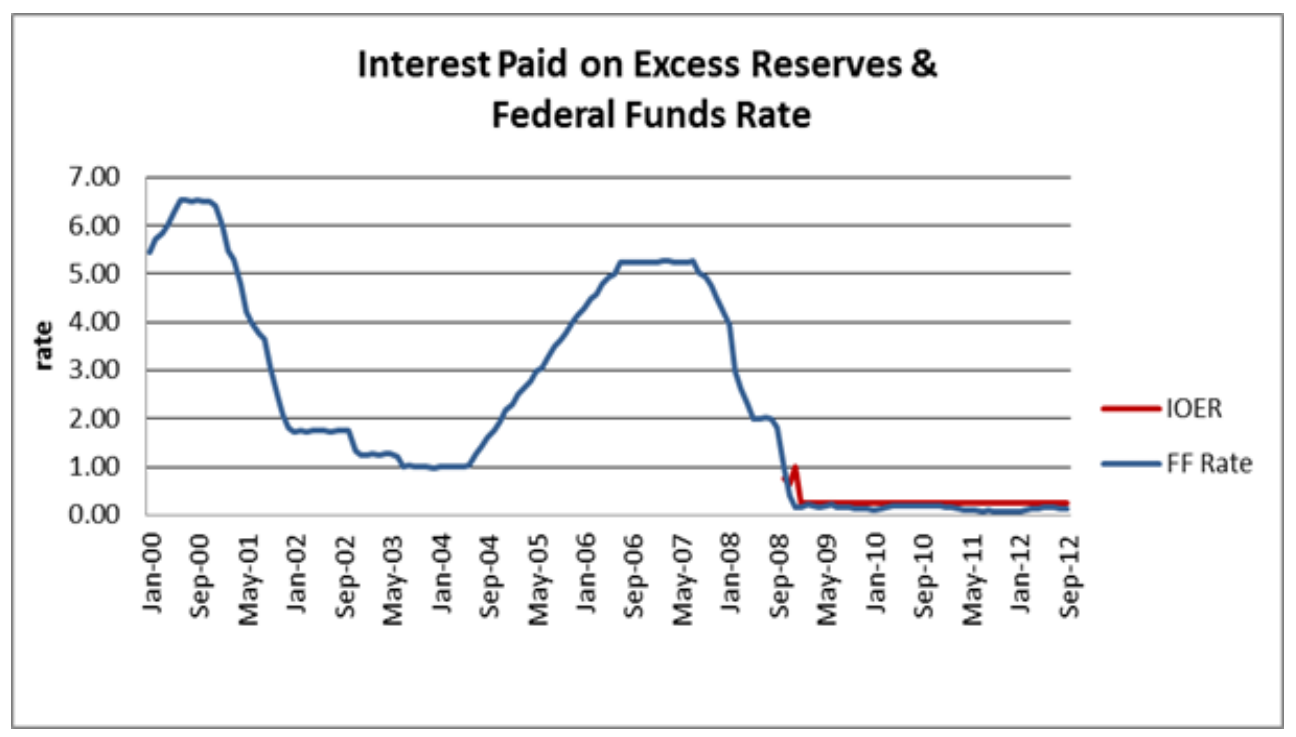

Figure 4. Interest Paid on Excess Reserves and Federal Funds Rate.

Jose Berrospide [5] found that this uncertainty about the future and concern about past decisions has had a large impact on banks deciding to hold on to higher than normal levels of excess reserves. His research found that banks' predicted losses in investments and higher levels of reserves for future loan losses were the "key driver of liquidity hoarding". Figure 3 shows that at the start of 2008, banks began experiencing large loan losses at the same time when investments were losing value.

An alternate reason for the reluctance for banks to release their liquidity could be the new low federal funds rate. The high level of open market purchases by the Federal Reserve has caused the federal funds rate to stay quite low (FRED). In fact, the interest paid on reserves is now higher than the federal funds rate (FRED). Banks are able to earn more money by holding on to completely risk free excess reserves than by selling them to other banks on the potentially risky federal funds market. Ronald McKinnon (2010) explains that when the "risk-free federal funds rate is close to zero, banks with excess reserves will not bother parting with them for a derisory yield". Figure 4 demonstrates the dramatic change in the federal funds rate and the introduction of interest on excess reserves. In the past, the federal funds market could be a decent way for banks to make a profit, but since the recession and the new payment on excess reserves, the rate has remained quite low. Ben Bernanke (2010) mentioned this issue in his testimony. He explained that because of the low federal funds rate, the market has "declined considerably" and the rate may now be a "less reliable indicator than usual of conditions in short-term money markets". The Federal Reserve may start to rely more on other rates to target since they have reached the lower bound for the federal funds rate. Because of this, the interest rate on excess reserves may play a larger role in monetary policy in the future. 


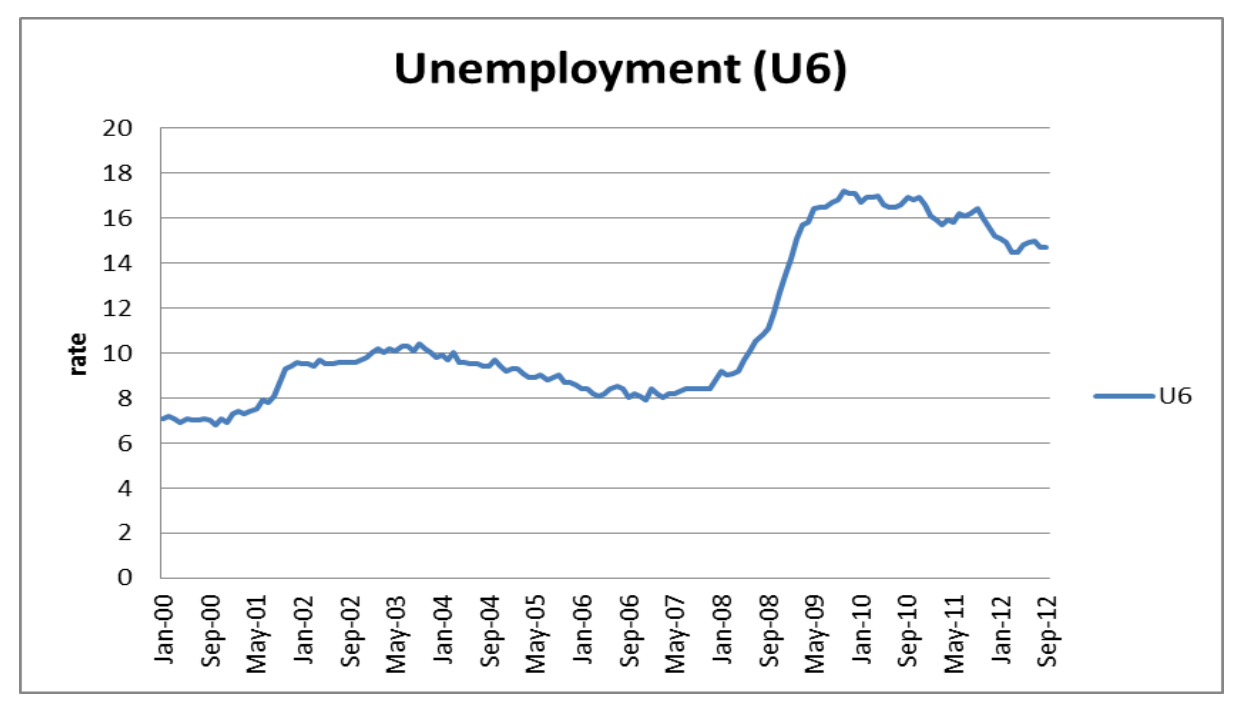

Figure 5. Unemployment (2000-2012)

Also, the potential for future lending has decreased because of the "long slump" that has accompanied the 2008 recession (Hall, 2010). Robert Hall (2010) points out that "households borrowed much more than usual and used the proceeds to buy more houses and cars than usual" when times were good, but after the financial crisis, banks began to use "tighter credit standards" for new borrowers and it became more difficult to receive a loan. Even though we have officially now been out of a recession since June of 2009 , the unemployment rate has continued to stay higher than previous levels as show in Figure 5. If we look at the unemployment rate data, which includes "all marginally attached workers plus total employed part time for economic reasons" the rate is quite high compared to before the crisis (FRED). This rate may also indicate an unwillingness for businesses to hire full time employees and possibly a lower demand for business loans since they are not working at full potential. This new level of marginally employed and unemployed workers along with consumers recovering from borrowing too much when loans were freely available may have an effect on a bank's willingness to lend current funds. The perceived risk for future lending to consumers is still quite high.

\section{Methodology}

The model hypothesis is that banks will hold higher levels of reserves when the interest paid on them is higher than the federal funds rate. Banks will also evaluate their past loan losses and potential losses from security investments and if there are high predicted losses, they will hold higher levels of liquidity. As a way to gauge future potential risk, banks will lend to people who are fully capable of repaying loans and for most consumers, this will be through full time employment.

Based on the aforesaid hypothesis, we postulate the following regression model.

$$
\% \mathrm{ER} / \mathrm{TR}=\beta_{0}+\beta_{1}(\mathrm{IOER}-\mathrm{FFR})+\beta_{2}(\mathrm{ALLL} / \mathrm{TR})+\beta_{3}
$$$$
\text { (Gain-Loss/TR) }+\beta_{4}(\mathrm{U} 6)+\varepsilon
$$

Where,

$\mathrm{ER}=$ excess reserves

$\mathrm{RR}=$ required reserves

$\mathrm{TR}=$ total reserve

IOER $=$ interest on excess reserve

$\mathrm{FFR}=$ federal fund rate

ALLL $=$ allowance for loan and lease loses

Gain/Loss $=$ unrealized gains or losses on available for sale securities

$\mathrm{U} 6=$ unemployment rate

Dummy $=1$ expansionary periods vs. 0 recessionary periods

The dependent variable $(\% \mathrm{ER} / \mathrm{TR})$ is the percentage of excess reserves in relation to total reserves. This number will give a better indication of the actual increase in excess reserves instead of simply looking at the dollar amount of excess reserves, since consumers may deposit more money during and right after a recession and both excess and required reserves may increase. The independent variables are (IOER-FFR) the difference between the interest paid on reserves and the federal funds rate, (ALLL/TR) allowance for loan and lease losses in relation to total reserves, (G,L/TR) unrealized gains or losses on available for sale securities in relation to total reserves, and (U6) the unemployment rate which also includes part time workers for economic reasons. This model, unfortunately, do not include two important explanatory variables, "banks' Tier 1 capital assets" and "banks' average leverage ratio" which are a comparison of a bank's liabilities compared to its equity (Lanchester, 2010). These two variables could indicate the health of a bank and therefore, its desire to hold precautionary reserves. However, in 2007, many banks created certain loan products called "Special Purpose Vehicles" to move assets off their balance sheets and to lower their reported leverage and assets. As a result, this process of SPV would most likely cause data to be 
inaccurate. Note also that the data is not readily available from the first place.

This model will be used to gauge a bank's decision-making process when deciding to hold higher levels of excess reserves. Are banks worried about past risky loans or bad investments or concerned with potential future risk? Is the new interest payment on excess reserves the key reason for banks to choose to hold their own liquidity instead of borrowing it when higher levels of reserves are needed? This paper tries to find answers to all these questions through our proposed regression model.

\section{Results and Discussion}

To begin with, we compare the mean score of the percentage of excess reserves in relation to required reserves across two periods. The first period goes from January 2000 to September 2008, just before the Federal Reserve began paying interest on reserves; while the second period goes from October 2008 to December 2012. Prior to October 2008, the mean percentage rate of ER/RR was $4.35 \%$, but after October the mean rate was $1483 \%$. This is quite a dramatic increase and has shown to be persistently high.

When evaluating the significance of the independent variables, the time from January of 2000 to September of 2008 was isolated to check if banks were considering these variables prior to the crisis and recession in 2007/2008.

Table 1. Dependent Variable: The percentage of Excess Reserve to Required Reserve ratio

\begin{tabular}{|c|c|c|c|}
\hline $\begin{array}{c}\text { Estimated } \\
\text { Variables }\end{array}$ & Coefficents & $\mathrm{t}$-value & $\mathrm{P}$ - value \\
\hline Intercept & -0.5161 & -2.23 & 0.24 \\
\hline IOER-FFR & 0.0327 & 0.67 & 0.39 \\
\hline ALLL/TR & 0.0011 & 1.33 & 0.31 \\
\hline Gain-Loss/TR & -0.0012 & -0.79 & 0.39 \\
\hline Unemployment & 0.0322 & 0.81 & 0.40 \\
\hline Dummy & 0.0441 & 4.32 & 0.3742 \\
\hline Adjusted $\mathrm{R}^{2}$ & & $22.5 \%$ & \\
\hline
\end{tabular}

*significance at $10 \%$ level, $* *$ significance at $5 \%$ level, $* * *$ significance at $1 \%$ level

The results from (Table 1) show that the explanatory variables are insignificant. That is, during the period from January 2000 to September 2008, banks seemed not to be concerned about the lenders' status or had no losses in loans or investments. The unemployment rate is also insignificant to lenders. This may seem surprising to think that banks were unconcerned with a borrower's ability to repay a loan. However, since most banks had plans to sell the loan on the secondary market, they didn't really care if it would be repaid or not (Lanchester, 2010). In fact, some loans were so-called "NINJA loans: No Income, No Job or Assets" and banks were only concerned with making the loan in order to increase their profit regardless of the lenders' abilities to repay. The coefficient of determination, adjusted $\mathrm{R}^{2}$ is only
$22.5 \%$ which means the explanatory variables explain very little in a bank's decision to hold on to excess reserves. Note that the Federal Reserve was not paying interest on excess reserves during this time, so the federal funds market was the only option for earning interest besides loans or security purchases.

Consequently, we will run another regression using the entire twelve years of data, from January 2000 to December 2012, with 153 observations, and adding a dummy for recessionary-expansionary periods. Using the entire data set allows us to track the influence the Federal Reserve's policy in the aftermath of the 2007-2008 financial crisis. Results displayed in Table 2 are significantly different from those reported in Table 1. Table 2 displays the effects of the banking crisis of 2007/2008 and banks' reactions to the crisis.

Table 2. Dependent Variable: The percentage of Excess Reserve to Required Reserve ratio

\begin{tabular}{|c|c|c|c|}
\hline $\begin{array}{c}\text { Estimated } \\
\text { Variables }\end{array}$ & Coefficents & t- value & P-value \\
\hline Intercept & -8.7231 & $-1.3702^{* * *}$ & 0.6321 \\
\hline IOER-FFR & 0.8185 & $5.7834^{* * *}$ & 0.0000 \\
\hline ALLL/TR & 0.0456 & $3.0014^{* *}$ & 0.0001 \\
\hline Gain,Loss/TR & 0.0196 & $3.3483^{* * *}$ & 0.0001 \\
\hline Unemployment & 2.0054 & $4.7598^{* * *}$ & 0.0000 \\
\hline Dummy & 3.0412 & 1.5001 & 0.2501 \\
\hline Adjusted $\mathrm{R}^{2}$ & & $86 \%$ & \\
\hline
\end{tabular}

*significance at $10 \%$ level, $* *$ significance at $5 \%$ level, $* * *$ significance at $1 \%$ level

Significantly different from the result of the first regression, all the explanatory variables become significant and the coefficient of determination, adjusted $\mathrm{R}^{2}$ jumps to $86 \%$. The unemployment rate variable shows the highest effect on banks decision to hold higher levels of excess reserves. When unemployment increases by one percent, the ratio of excess reserves will increase by 2 percent. Lenders now seem to pay attentions to some criteria, such as having a job, before granting a loan. Not surprisingly, the interest on reserves minus the federal funds rate is also significant indicating banks' preferences to hold on to higher levels of excess reserves when the interest paid for excess reserves is higher than the federal funds rate. That is, as the opportunity cost of granting a loan in federal funds market increase, banks favor the high interest rate earned from the Federal Reserve than the lower federal funds rate. Both the loan loss and unrealized variables show high significance as well. This reveals that banks began to be concerned with losses from past loans and investments prior to 2007-2008. This pushed banks to stop making risky loans to future borrowers. Even though the Federal Reserve was willing to purchase many of the risky and potentially defaulting mortgage-backed securities, many were purchased with the promise that banks would repurchase them in the future. As a result, banks were reluctant to hand out new loans with the fear that the old loans may still be considered a loss 
(Bernanke, 2010). These independent variables combined seem to support the hypothesis that banks have a desire to hold on to borrowed reserves, even if only for precautionary reasons. This indicates that although the interest paid on excess reserves is only $0.25 \%$, banks aren't willing to lend with an increased risk premium, and also aren't willing to part with their excess reserves to other banks when the health of individual banks is unknown.

An increase in the excess reserve in the aftermath of the crisis contributed significantly to the credit crunch since 2008. As a result, loanable funds market starts to witness a sudden tightening of the conditions required to obtain a loan from a bank. Note that the reduction of the credit during 2008 an onward is independent of the changes in interest rate. In this case, we can conclude that the reduction of the availability of credit is mainly because what is known as "flight to quality" by banks at which these banks seek less risky investment.

In 2005, Rajan warned in his paper, the financial development make the world riskier, that the phase of easy credit and inappropriate and relaxed lending practices by the U.S. bankers will result eventually in a financial crisis. As he expected, the crisis occurred in late 2007 resulting in changes in monetary conditions, paying interest on excess reserves, tightening credit requirements, and bailing out several "on the brink of the failure" companies, which all contributes to the increase in the excess reserves held by the U.S. banks.

This model, unfortunately, does not include two important explanatory variables, "banks' Tier 1 capital assets" and "banks' average leverage ratio" which are a comparison of a bank's liabilities compared to its equity (Lanchester, [16]). These two variables could indicate the health of a bank and therefore, its desire to hold precautionary reserves. However, in 2007, many banks created certain loan products called "Special Purpose Vehicles" to move assets off their balance sheets and to lower their reported leverage and assets. As a result, the data needed many times are unavailable or limited to only the largest banks and including incomplete information would result in inaccurate results. Since this debt to equity ratio is unknown, the level of precautionary reserves is also difficult to confirm. Technically, any reserves a bank holds over the required reserve level could be seen as precautionary reserves, but to find an exact amount out of the total of excess reserves would be nearly impossible when banks are able to hide their riskier loans as previously noted. Also, the introduction of interest payments on excess reserves changed the cost of holding reserves and therefore banks may not see a difference between their level excess reserves and precautionary reserves.

\section{Conclusions}

The panic of 2007-2008 and the subsequent recession was the most serious and severe global financial crisis since the Great Depression. In the aftermath of the crisis, the U.S. economy suffered from large amount of loan defaults, which resulted in major losses to commercial and investment banks. This has led to a freeze in the interbank market and a consequent increase in excess reserves. Tightening the credit requirements and the interest payments on the excess reserve by the Federal Reserve have also contributed to the increase in the excess reserves.

In fact, interest payments on excess reserves may be a good monetary policy tool when the Federal Reserve seeks to slow down the economy. In the current circumstances, however, this policy seems to be hindering banks' activity. As Bernanke explained in 2010, once the target interest rate hit close to zero, the Federal Reserve needs other ways to influence long-term interest rates. He also argues that the interest payments on excess reserves are a tool to be used to get out of its "currently very accommodative policy," not as a tool to stimulate the current economy.

The results of this research came in support of two facts. First, the very low excess reserve prior to the financial crisis was mainly because of the extremely low interest rate and mortgage rates starting year 2000. These low rates were also accompanied by very "easy" credit requirements, which allowed people with little hope to get a loan, such as those who are unemployed, to now obtain one. As the crisis started to unfold by the beginning of 2007, the number of defaults on both subprime and adjustable-rate mortgages began to increase and quickly thereafter. Several banks declared bankruptcy, while some other banks acquired others. As a result, fear was widespread among lenders, leading them to tighten the credit conditions requirements. The new requirements, along with the interest payments on excess reserves, encouraged banks to pile up reserves, which led to unprecedented increases in excess reserves in the aftermath of the financial crisis.

This project looked at either all banks or the largest domestically chartered commercial banks (whichever were available) for data analysis. A future research could better investigate banks' liquidity hoarding if banks were separated by size or by levels of excess reserves held. A future project could also evaluate a bank's decision to hold higher levels of excess reserves and their changes in lending practices.

\section{REFERENCES}

[1] Acharya, Viral V., D.gromb, and T. Yorulmazer, Imperfect Competition in the Interbank Market for Liquidity as a rationale for Central Banking. Working paper, New York University Stern School of Business.

[2] 2009Akhtar, M. A, Understanding Open Market Operations. Federal Reserve Bank of New York: Public Information Department.1997

[3] Allen, F. and D. Gale, Financial Fragility, Liquidity, and Asset Prices, Journal of the European Economic Association. Vol.3. PP. 533-546, 2004

[4] Bernanke, B. S. FRB: Testimony--Bernanke, Federal 
Reserve's exit strategy--February 10, 2010. Board of Governors of the Federal Reserve System, 2010.

[5] Berrospide, J., Liquidity hoarding and the financial crisis: An empirical evaluation. Federal Reserve Bank of New York Staff Report, 2012.

[6] Domestic open market operations during 2011. (2012, March). A Report Prepared for the Federal Open Market Committee by the Markets Group of the Federal Reserve Bank of New York, March 2012.

[7] Diamond.D and R. Rajan. Fear of fire sales, Illiquidity seeking and the credit freeze. Quaterly Journal of Economics. Forthcoming.

[8] Edlin, A. S., \& Jaffee, D. M. Show me the money. Economists' Voice, 6(4), 1-5, 2009.

[9] Ennis, H. M., \& Wolman, A. L., Large excess reserves in the U.S.: A view from the cross-section of banks. Federal Reserve Bank of Richmond, Working paper No. 12-05, 1-46, 2012.

[10] Gale, D. \& Yorulmazer, T. Liquidity Hoarding, Federal Reserve Bank of New York Staff Report, Staff Report \# 488, 2011.

[11] Gorton, G. B., Slapped by the invisible hand. New York, New York: Oxford University Press, 2010.
[12] Hann D and J WV D End, Banks response to funding liquidity shocks: Lending adjustment, Liquidity hoarding and resales. De Nederlandsche Bank. Working Paper, 2011.

[13] Heider. F, M. Hoerova, and C. Holthausen (2008). Liquidity Hoarding and Interbank Market Spreads: The role of Contemporary Risk, Working Paper, European Central Bank (ECB), 2008.

[14] Hall, R. E. The long slump. NBER Working Paper No. 16741, $1-66,2010$.

[15] Keister, T., \& McAndrews, J., Why are banks holding so many excess reserves? Federal Reserve Bank of New York Staff Reports, No. 380, 1-15, 2009.

[16] Lanchester, J., I.O.U: Why everyone owes everyone and no one can pay. New York: Simon \& Schuster, 2010.

[17] McKinnon, R. I., Beggar-thy-neighbor interest rate policies. Journal of Policy Modeling, 33(5), 759-775, 2010.

[18] Meyer, P. A., Monetary economics and financial markets. Homewood, Ill: R.D. Irwin. 1982.

[19] Rajan, R. , Has Financial Development made the World Riskier?, NBER Working paper \#11728, 2005.

[20] Ramos. A., Deposit Insurance, Bank Capital Structures and the Demand for Liquidity. Working Paper Series (WP-96-8). Federal Reserve Bank of Chicago, 1996. 